\title{
Mature Cystic Teratoma of Skull Base and Attached to the Wall of'Third Ventricle
}

\author{
Kafa Tabanının Ücüncü Ventrikül Duvarına Yapışmıs Matür Kistik \\ Teratomu
}

Peizhi ZHOU, Youping LI, Zhangchao YANG, Jiang SHU

Sichuan University, West China Hospital, Department of Neurosurgery, Chengdu, Sichuan Province, P.R. China

Corresponding Author: Jiang SHU / E-mail: jiangshu2000@126.com

\section{ABSTRACT}

An 18-year-old man was admitted with a 1-month history of headache and disturbed visual acuity. Neurological examination revealed a visual field defect of bilateral inferotemporal areas. The endocrinological examination was normal. Magnetic resonance imaging (MRI) revealed a large cystic lesion in the anterior and middle skull base. Total resection was performed via a right frontal-lateral approach. At operation, a well-demarcated cyst pressed the optic nerve and the pituitary stalk, and attached to the wall of the third ventricle via a nodule. Histological examination confirmed a mature teratoma. His vision recovered and no recurrence was found during a follow-up period of 16 months.

KEYWORDS: Mature teratoma, Skull base, Cystic

öz

18 yaşında bir erkek hasta 1 aylık baş ağrısı ve görme bozukluğuyla geldi. Nörolojik inceleme bilateral inferotemporal görme alanı defekti ortaya koydu. Endokrin muayene sonuçları normaldi. Manyetik rezonans görüntüleme (MRG) anterior ve orta kafa tabanında büyük bir kistik lezyon gösterdi. Sağ frontal-lateral yaklaşımla total rezeksiyon yapıldı. Ameliyatta iyi demarkasyonlu bir kist optik sinir ve hipofiz sapına bastırmaktaydı ve üçüncü ventrikülün duvarına bir nodül vasıtasıyla tutunmuştu. Histolojik inceleme matür bir teratomu ortaya koydu. Görme düzeldi ve 16 aylık takipte bir tekrarlama saptanmadı.

ANAHTAR SÖZCÜKLER: Matür teratom, Kafatası tabanı, Kistik

\section{CASE ILLUSTRATION}

Teratomas are commonly located in the gonads, anterior mediastinum and retroperitoneum. Intracranial teratomas are rare and mainly occur in the pineal region, and are frequently found in children and young adult $(2,3)$. Cystic teratomas arising from the wall of third ventricle are uncommon and most of them are malignant. Teratoma comprising only mature elements is extremely rare and the anatomic site of
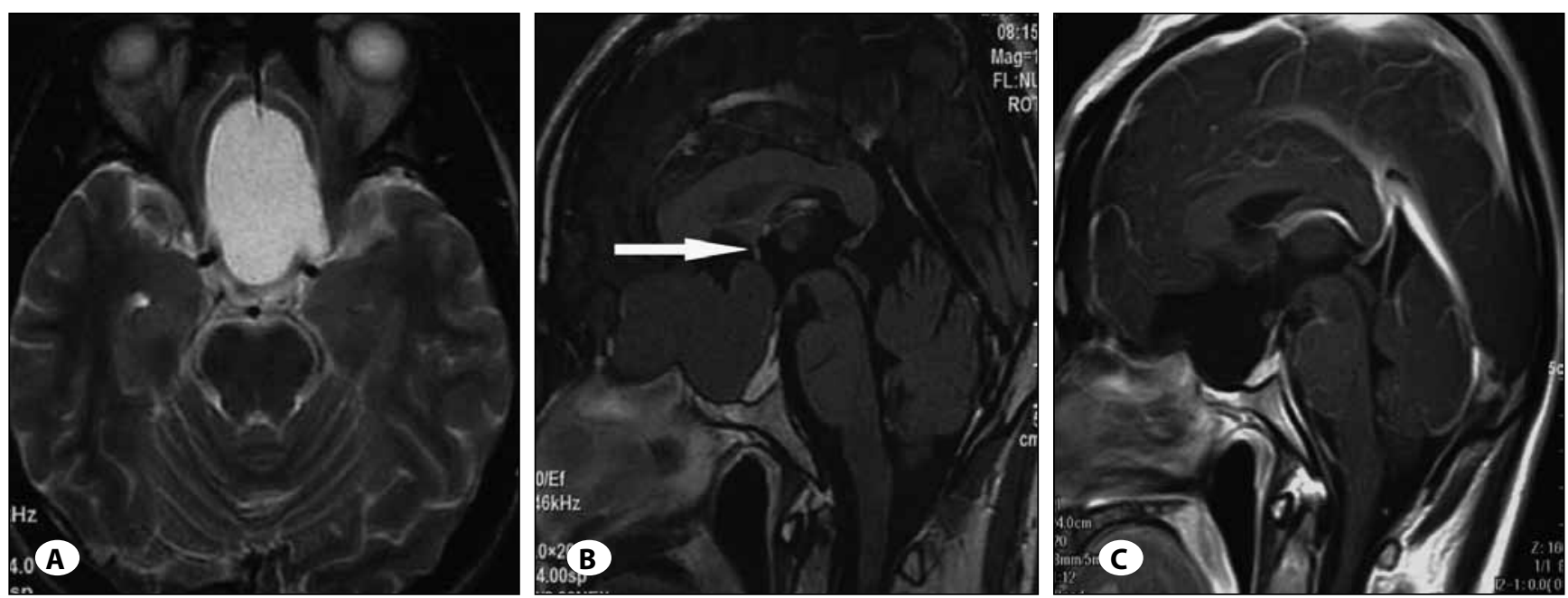

Figure 1: The lesion is isointense on T1-weighted and hyperintense on T2-weighted images. The attachment of the lesion is shown (arrows). 

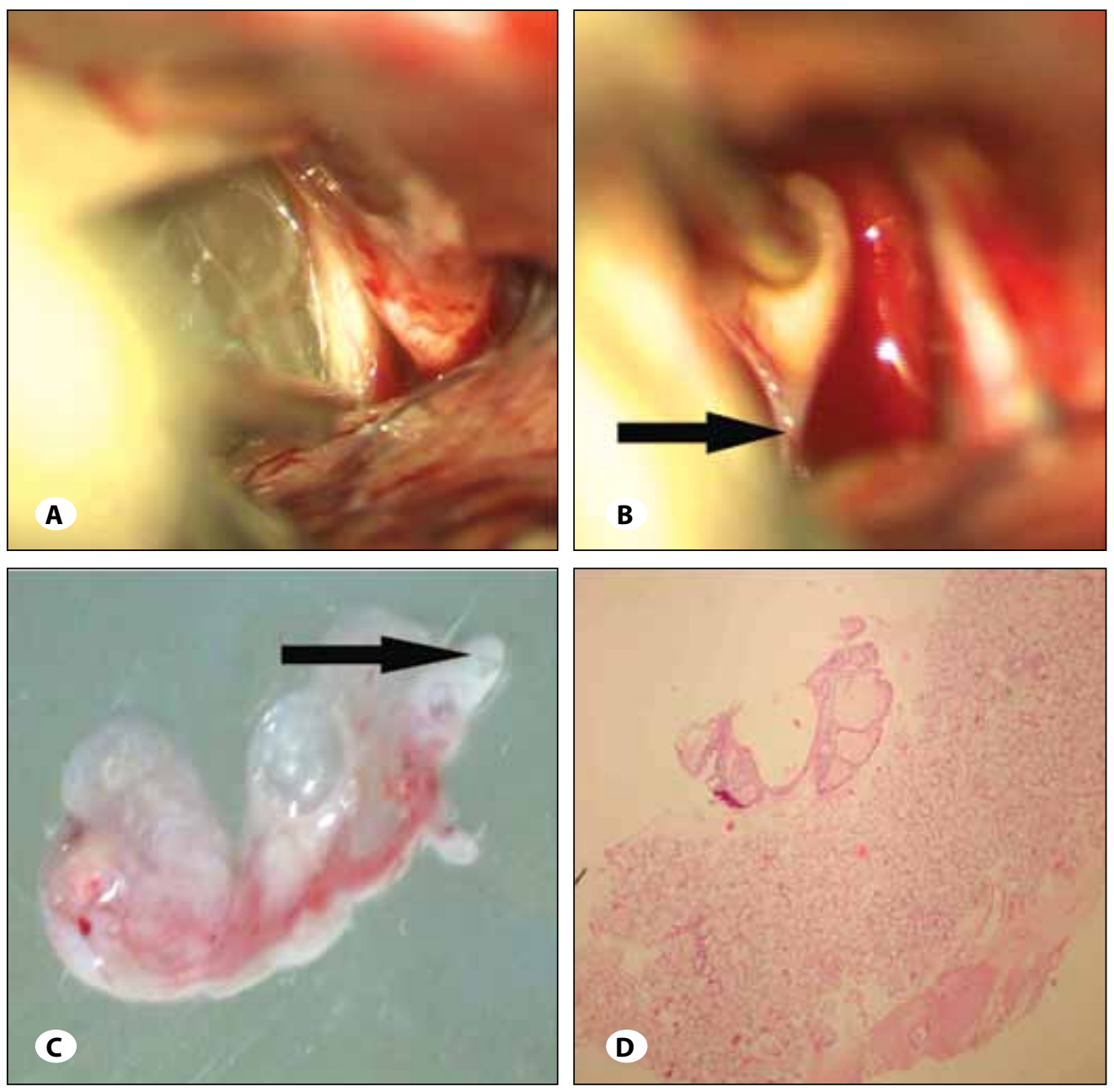

Figure 2: The lesion during the operation and the histological findings with attachment to the anterior wall of the third ventricle (arrows).

origin is seldom described according to both the MRI and operation findings.

Although our patient's lesion pressed on the pituitary stalk and the pituitary, all the pituitary hormones were within normal levels, maybe because of the chronic and soft pressure from the cyst. The gelatinous content of this tumor was isointense on T1-weighted and hyperintense on T2-weighted images (Figure 1A-C). The origin of the tumor was attached to the anterior wall of the third ventricle, which was confirmed during the operation, and the attachment stalk was slightly enhanced (Figure $2 A, B$ ). Usually the precise anatomical origin is difficult to determine for large and malignant germinomas and we determined the details during the microsurgery and based on the MRI. Histologicaly, mature teratoma is identified by the presence of differentiated neuroectodermal, mesodermal and endodermal elements (Figure 2C, D) (3).

Unlike immature teratomas, mature teratomas are benign and radioresistant and malignant transformation is very rare (4). Surgical resection is the main treatment of intracranial mature teratoma, and the content of the cyst must aspirated carefully to avoid aseptic meningitis. Early treatment may avoid the occurrence of the pituitary dysfunction, Diabetes insipidus and postoperative cerebrospinal fluid (CSF) leakage because of the compression of the pituitary and skull base bone from the lesion.

\section{REFERENCES}

1. Agrawal M, Uppin MS, Patibandla MR, Bhattacharjee $S$, Panigrahi MK, Saradhi V, Rani JY, Purohit AK, Challa S: Teratomas in central nervous system: A clinico-morphological study with review of literature. Neurol India 58(6): 841-846, 2010

2. Echevarria ME, Fangusaro J, Goldman S: Pediatric central nervous system germ cell tumors: A review. Oncologist 13:690-699, 2008

3. Jurban RF, Finlay J: Central nervous system germ cell tumors: Controversies in diagnosis and treatment. Oncology 19: 705-711, 2005

4. Parithivel K, Jagannathan JP, Krajewski K, O'Regan K, Quick CM, Ramaiya N, Campos S: Ovarian squamous cell carcinoma arising from mature cystic teratoma. Cancer Imaging 11: 67-69, 2011 